\title{
Deep Learning Approach for cognitive competency assessment in Computer Programming subject
}

\author{
Shahidatul Arfah Baharudin \\ Malaysian Institute of Information Technology, \\ Universiti Kuala Lumpur, \\ 1016, Jalan Sultan Ismail, 50250 Kuala Lumpur, Malaysia \\ shahidatularfah@unikl.edu.my \\ Adidah Lajis \\ Malaysian Institute of Information Technology, \\ Universiti Kuala Lumpur, \\ 1016, Jalan Sultan Ismail, 50250 Kuala Lumpur, Malaysia \\ adidahl@unikl.edu.my
}

\begin{abstract}
This research examines the competencies that are essential for an lecturer or instructor to evaluate the student based on automated assessments. The competencies are the skills, knowledge, abilities and behavior that are required to perform the task given, whether in a learning or a working environment. The significance of this research is that it will assist students who are having difficulty learning a Computer Programming Language course to identify their flaws using a Deep Learning Approach. As a result, higher education institutions have a problem with assessing students based on their competency level because; they still use manual assessment to mark the assessment. In order to measure intelligence, it is necessary to identify the cluster of abilities or skills of the type in which intelligence expresses itself. This grouping of skills and abilities referred to as "competency". Then, an automated assessment is a problem-solving activity in which the student and the computer interact with no other human intervention. This review focuses on collecting different techniques that have been used. In addition, the review finding shows the main gap that exists within the context of the studied areas, which contributes to our key research topic of interest.
\end{abstract}

Keywords: Cognitive competency, deep learning, automated assessment, Bloom's Taxonomy, computer programming

\section{INTRODUCTION}

Assessment is a core and critical requirement in an educational system since it contributes to the great extent affects of students' learning [1][2]. Therefore, deep learning approach is applies to enrich and enhance the lecturer assessment. A good assessment is where the lecturers are well understanding on the assessment principles includes assessment terminology, development and use of assessment methodologies and techniques, assessment quality standards and any alternative to traditional measurements of learning. Because of that, it does require integration in assessment practices, theories, philosophies to support teaching and learning in education.

The lecturer is also served as facilitator, a mentor or a coach to guide the process of students' learning. The student is responsible for his or her own learning. The students should also get trainings for developing various competencies, including cognitive, meta-cognitive, social and affective competencies, for the success of their future. Therefore, with deep learning, the learning process is internally motivated and is associated with an intention to understand, rather than to simply pass an assessment task. In this connection, assessment has been identified as a powerful aid to engage students into a more in-depth learning process and transform them into reflective practitioners.

By applying deep learning in education, the research on pedagogies of assessment education can be enriched. Moreover, deep learning can be applied either in face-to-face teaching or online learning or blended learning itself. Therefore, the structure of the paper is as follows: Section II describes the main problem in computer programming subject . Section III discuss on Competency-Based Education and Bloom Taxonomy. Section IV discuss on review of cognitive competency assessment techniques. Section V, explains about the deep learning in the assessment of cognitive competency. Section VI, discuss on to conclude the paper's finding. 


\section{THE MAIN PROBLEM IN COMPUTER PROGRAMMING SUBJECT}

In 2019, Bennedsen and Caspersen [4] has conducted a worldwide survey for the research on failure rate for programming course. The total respondent during 2019 is 170 response to their survey. Fig. 1 shows the number of respondents per continent is Africa, Asia, Australia, Europe, North America and South America.

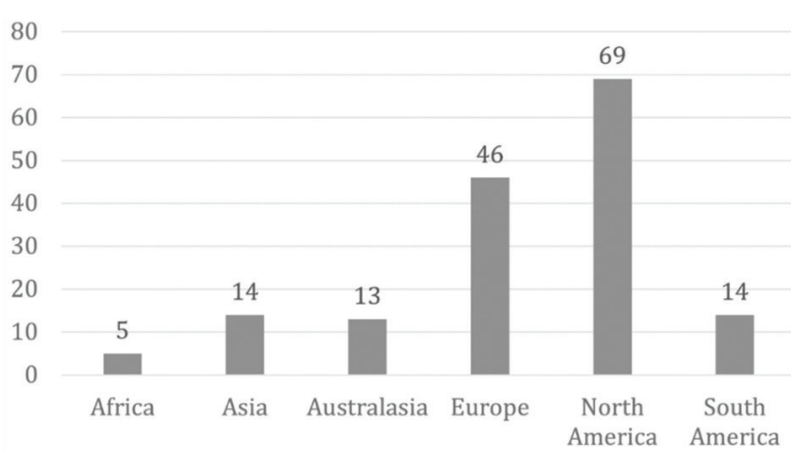

Fig. 1. Number of respondents per continent

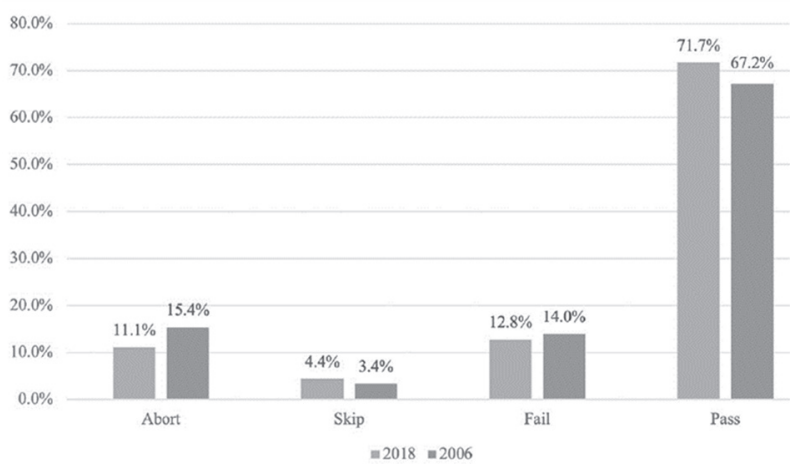

Fig. 2. Pass, Fail, Abort and Skip Rate: aggregate

Based on Fig. 2, each of the respondents were asked to give a number for abort which is the number of student aborting the course before final exam, skip is the number of students not showing up for the final exam but was allowed to, fail is the number of students who failed the course and pass is the number of students who passed the course. As a results, they found that the average failure is $28 \%$ based on Fig. 2 . The main reason they were uninterested in programming. Students believe that learning to program is difficult. They struggle to understand the program code and write a simple program. This research is also agreed by other researchers, while the student also already has a comfort level, difficulties in understanding the course content, time management issues and expectations and perfections of not getting enough help from their lecturer [5][6]. Other than that, the student also demotivated the student to learn programming [7]. This reason also agrees with Nurul Farahin et al. where the major problem in computer programming is lack of problem-solving skills, no prior knowledge, low motivation, poor mathematical knowledge, peer influence and lack of future expectation [8].

\section{COMPETENCY-BASED EDUCATION AND BLOOM'S TAXONOMY}

Computer-Based Education (CBE) is one of the concept to reflect human competency motor, intellectual and emotional competency. Using CBE, it can measure learning progress by the student. CBE also is the smaller concept of outcome-based leaning (OBE). The competence student is those who can and want to interact effectively three kinds of environment presented by the socially ascribed, self-selected and self-developed roles [9].

OBE is defined as an education system that focuses on learning outcomes rather than educational curriculum content. Learning outcomes, for example, quantified in terms of information, abilities, attitudes gained during the learning process. [10]. It covers three learning domains, which are the Psychomotor, Cognitive and Affective domains. They have implemented these three learning domains in various ways.

Cognitive domain is the one where the student's cognitive activities are structured. Starting with the knowledge level and ending with the evaluation level of Bloom's Taxonomy [11]. There also some evidence that cognitive training able to improve cognitive function, which potentially slow cognitive decline and able to help the student. Cognitive domain deals with how a student acquires processes and utilizes the knowledge. For Affective domain, it is focused on attitude, motivation, willingness to take part, valuing what is being learn and discipline values into real life. The last one, psychomotor domain focuses on performing sequences of motor activities to a specific level of accuracy, smoothness, rapid or force. Underlying the motor activities is cognitive understanding [12]. Evidence of outcome is required to fulfill the shortage of the soft skill of an employee in the workplace [13].

Bloom's taxonomy of Educational Objectives is a classification system by an educational psychologist Benjamin Bloom who creates in year 1956. It focuses on developing thinking ability, which involves simple information acquisition to a more complex process [14]. Bloom's taxonomy contains six categories of cognitive skills ranging from lower-order skills that require less cognitive processing to higher-order skills that require deeper leaning and a greater degree of cognitive processing. Though in year 2001, the Bloom's Taxonomy has been revised [15]. Refer to Fig. 3. The differentiations into categories of higher-order and lower-order skills arose later.

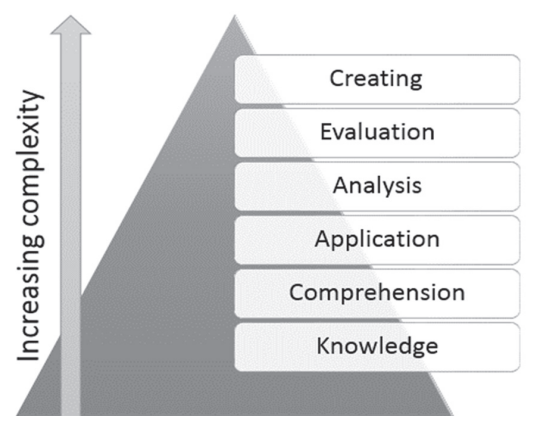

Fig. 3. Revised Bloom's Taxonomy 
For the older version of Bloom's Taxonomy, it consists Knowledge, Comprehension, Application, Analyzing, Evaluation and Creating. Knowledge is the foundational cognitive skill and refers to the retention of specific, discrete pieces of information like facts and definitions or methodology for example as the sequence of events in a step-by-step process. Comprehension is the meaning of the information that they encounter by paraphrasing it in their own words, classifying items in groups, comparing and contrasting items with other similar entities of explaining a principle to others. For comprehension, it is requires more cognitive processing than simply remembering information and learning objectives that address comprehension will help learners to incorporate knowledge into their existing cognitive schemas by which they understand the world [16]. Based on comprehension, it will allow student to learn how to use the knowledge, skills and techniques in a new situation via application, which is the third level of Bloom's taxonomy. For the higher level of Bloom's taxonomy is analysis. Analysis can break down a material into its constituent parts in order to comprehend its organizational structure. It is also where skills such as critical thinking come into play. Distinguish between facts and opinions and identify the claims that underlie the analysis. Following the analysis, the next level is synthesis. Synthesis entails creating a novel product in a specific situation. Its behavior is recombine the parts created during analysis to form a new entity where is differs from the original one. Finally, evaluation is the pinnacle of Bloom's Taxonomy. Evaluation is also an important aspect of critical thinking skills. It will show the student's ability to assess the worth of a material for a specific purpose using predetermined criteria and rationale. [17]. For the revised Bloom's taxonomy, refer to Table 1.

Table 1. Revised Bloom's Taxonomy

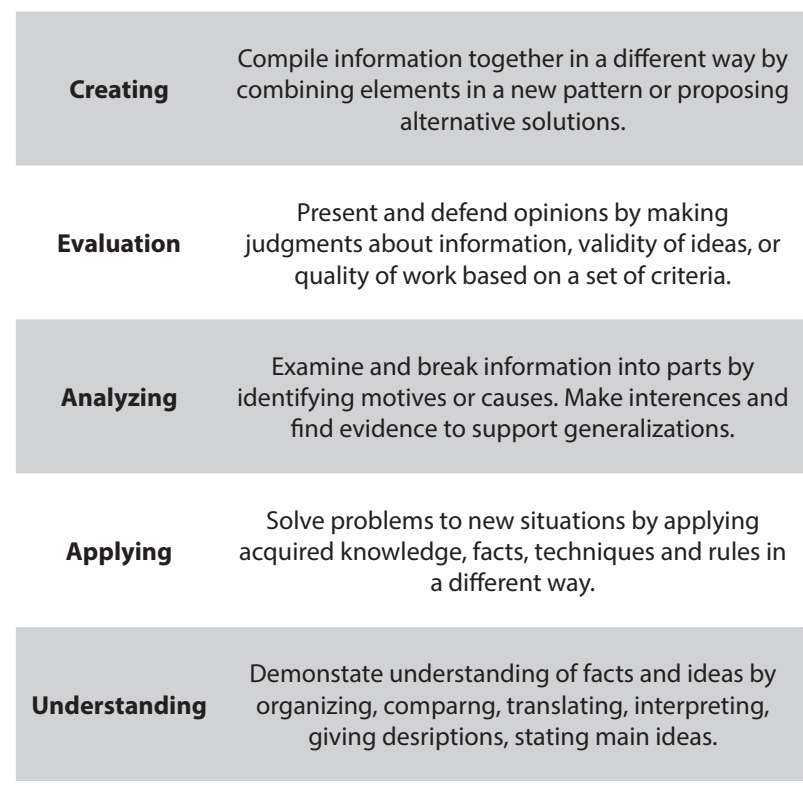

Retrieve relevant knowledge by recalling facts, Remembering terms, basic concept and answer from long-term memory.
In year 2019, [18] has used Bloom's Taxonomy as a scale for preparing the assessment questions, it quantified the competency level based on that. The results show that Bloom's Taxonomy is a beneficial tool for learning and assessing computer-programming subject.

\section{4. REVIEW OF COGNITIVE COMPETENCY ASSESSMENT TECHNIQUE}

Cognitive competency defined as critical thinking and creative thinking skills which effective problem solving, decision making, learning and development [19]. These criteria are important for the student to learn Computer Programming. Therefore, cognitive competency assessment follow by guideline from the Bloom's Taxonomy in the cognitive domain using automated assessment.

Table 2 illustrates the summarized of technique cognitive competency assessment which came from the previous research.

Table 2. Summarized of technique cognitive competency assessment

(C-Competency, NM-Not mentioned)

\begin{tabular}{|c|c|c|c|c|}
\hline 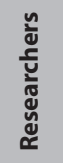 & Subjects & Level / Age & Techniqu-es & Focus \\
\hline [20] & $\begin{array}{l}\text { Comp. } \\
\text { Science }\end{array}$ & $\begin{array}{l}\text { Undergrad } \\
\text { and Schools }\end{array}$ & $\begin{array}{l}\text { NLP and info. } \\
\text { theory }\end{array}$ & C \\
\hline $\begin{array}{l}{[21]} \\
{[22]}\end{array}$ & $\begin{array}{l}\text { Introductory } \\
\text { course in } \\
\text { Computer } \\
\text { Literacy }\end{array}$ & $\begin{array}{l}\text { Undergrad } \\
\text { Students }\end{array}$ & LSA & NM \\
\hline $\begin{array}{l}{[23]} \\
{[24]} \\
{[25]}\end{array}$ & $\begin{array}{l}\text { Introductory } \\
\text { data structure } \\
\text { course }\end{array}$ & $\begin{array}{l}\text { Undergrad } \\
\text { students }\end{array}$ & Text Similarity & NM \\
\hline [13] & $\begin{array}{l}\text { Introduction } \\
\text { to } \\
\text { programming }\end{array}$ & $\begin{array}{l}\text { Undergrad } \\
\text { students }\end{array}$ & $\begin{array}{c}\text { Assessment } \\
\text { Framework } \\
\text { based on Bloom's } \\
\text { Taxonomy }\end{array}$ & C \\
\hline [26] & $\begin{array}{c}\mathrm{C}++ \\
\text { Programming }\end{array}$ & $\begin{array}{l}\text { Undergrad } \\
\text { Students }\end{array}$ & $\begin{array}{l}\text { Semi-automated } \\
\text { assessment }\end{array}$ & NM \\
\hline $\begin{array}{l}{[18]} \\
{[27]}\end{array}$ & $\begin{array}{c}\text { Computer } \\
\text { Programming }\end{array}$ & $\begin{array}{l}\text { Undergrad } \\
\text { students }\end{array}$ & $\begin{array}{l}\text { Rule-Based } \\
\text { Method }\end{array}$ & C \\
\hline [28] & $\begin{array}{c}\text { Parallel } \\
\text { Programming }\end{array}$ & $\begin{array}{l}\text { Undergrads } \\
\text { students }\end{array}$ & $\begin{array}{l}\text { Code Evaluation } \\
\text { and Debugging }\end{array}$ & NM \\
\hline [29] & $\begin{array}{l}\text { Computer } \\
\text { Methods }\end{array}$ & $\begin{array}{l}\text { Undergrads } \\
\text { students }\end{array}$ & $\begin{array}{c}\text { Computer } \\
\text { Adaptive Testing } \\
\text { Tools }\end{array}$ & $\begin{array}{l}\text { Non- } \\
\text { cognitive }\end{array}$ \\
\hline [30] & $\begin{array}{c}\text { Computer } \\
\text { Programming }\end{array}$ & $\begin{array}{l}\text { Undergrads } \\
\text { students }\end{array}$ & $\begin{array}{l}\text { Flexible and } \\
\text { systematic } \\
\text { teaching } \\
\text { framework }\end{array}$ & $C$ \\
\hline [31] & Programming & $\begin{array}{l}\text { Undergrads } \\
\text { students }\end{array}$ & $\begin{array}{c}\text { Online EasyHPC } \\
\text { Tool }\end{array}$ & NM \\
\hline
\end{tabular}




\begin{tabular}{|c|c|c|c|c|}
\hline 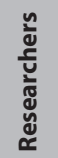 & Subjects & Level / Age & Techniqu-es & Focus \\
\hline [32] & Programming & $\begin{array}{l}\text { Undergrads } \\
\text { students }\end{array}$ & $\begin{array}{l}\text { Collaborative } \\
\text { Scenario- } \\
\text { TASystem tools }\end{array}$ & NM \\
\hline [33] & UML & $\begin{array}{l}\text { Undergrads } \\
\text { students }\end{array}$ & $\begin{array}{c}\text { Comprehensive } \\
\text { Approach }\end{array}$ & NM \\
\hline [34] & $\begin{array}{l}\text { Computer } \\
\text { Programming }\end{array}$ & $\begin{array}{l}\text { Undergrads } \\
\text { students }\end{array}$ & $\begin{array}{c}\text { Online Learning } \\
\text { system }\end{array}$ & C \\
\hline [35] & $\begin{array}{l}\text { Computer } \\
\text { Programming }\end{array}$ & $\begin{array}{l}\text { Undergrads } \\
\text { students }\end{array}$ & $\begin{array}{c}\text { Integration } \\
\text { Automated Test } \\
\text { Data Generation } \\
\text { and programming } \\
\text { assessment }\end{array}$ & NM \\
\hline [36] & $\begin{array}{l}\text { Computer } \\
\text { Programming }\end{array}$ & $\begin{array}{l}\text { Undergrads } \\
\text { students }\end{array}$ & $\begin{array}{l}\text { Software Testing } \\
\text { technique }\end{array}$ & NM \\
\hline [37] & Programming & $\begin{array}{l}\text { Undergrads } \\
\text { students }\end{array}$ & $\begin{array}{l}\text { Classical Test } \\
\text { Theory (CTT) or } \\
\text { Item Response } \\
\text { Theory (IRT) - } \\
\text { SIETTE }\end{array}$ & NM \\
\hline [38] & $\begin{array}{l}\text { Computer } \\
\text { Programming }\end{array}$ & $\begin{array}{l}\text { Undergrads } \\
\text { students }\end{array}$ & $\begin{array}{l}\text { 2TSW - testing- } \\
\text { based approach }\end{array}$ & NM \\
\hline [39] & $\begin{array}{l}\text { Chinese } \\
\text { Subject }\end{array}$ & $\begin{array}{l}\text { Undergrads } \\
\text { students }\end{array}$ & NLP & NM \\
\hline [40] & $\begin{array}{l}\text { Computer } \\
\text { Programming }\end{array}$ & $\begin{array}{l}\text { Undergrads } \\
\text { students }\end{array}$ & $\begin{array}{l}\text { Metacognitive } \\
\text { Support }\end{array}$ & C \\
\hline [41] & $\begin{array}{c}\text { Object- } \\
\text { Oriented } \\
\text { Programming }\end{array}$ & $\begin{array}{l}\text { Undergrads } \\
\text { students } \\
\text { And High } \\
\text { School }\end{array}$ & $\begin{array}{l}\text { Competency } \\
\text { Structure Model } \\
\text {-COMOOP }\end{array}$ & C \\
\hline
\end{tabular}

Based on data in Table 3, it is possible to propose the cognitive competency assessment can still assist the student. Several studies have been used to identify the cognitive problem. Other than that, the research did not mention the focus on cognitive. Some of the research is using the Mobile Learning application to investigate the factors that influence student's learning performance and evaluate the effectiveness of mobile learning to use the Learn $\mathrm{C}$ application in programming subjects. The findings shows that a variety factors that affect the student learning. There are misunderstanding, lack of practices, poor logical thinking and problem solving [8] . However, there is no mention of them being able to determine their cognitive level. Only one research using the Bloom's Taxonomy as a benchmark to evaluate the student. Thus, the study concludes that the cognitive level of Bloom's Taxonomy as a tool for the assessing a student's competency in programming is appropriate and cable of reducing the high failure rate among student enrolled in Computer Programming subjects [13].

\section{DEEP LEARNING IN THE ASSESSMENT OF COGNITIVE COMPETENCY}

Deep learning is a class of machine learning algorithms that employ multiple layers to represent various levels of abstraction. It comprises of an input layer, an output layer and a few hidden layers. It showed this assessment in Table 3.
Table 3. Summarized of deep Learning in the cognitive competency assessment (C-Competency, NM-Not mentioned)

\begin{tabular}{|c|c|c|c|c|}
\hline 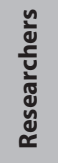 & Subjects & Level / Age & Techniqu-es & Focus \\
\hline [42] & Kaggle ASAP & $\begin{array}{l}\text { 7th to } 10 \text { th } \\
\text { grader }\end{array}$ & $\begin{array}{c}\text { LSTM classification } \\
\text { and regression } \\
\text { task }\end{array}$ & NM \\
\hline [43] & Kaggle ASAP & $\begin{array}{l}\text { 7th to } 10 \text { th } \\
\text { grader }\end{array}$ & $\begin{array}{l}\text { LSTM- CNN- } \\
\text { attention- based }\end{array}$ & NM \\
\hline [44] & $\begin{array}{c}\mathrm{IT}, \\
\text { Engineering, } \\
\text { Management }\end{array}$ & $\begin{array}{l}\text { Higher } \\
\text { education }\end{array}$ & NLP, CNN & C \\
\hline [45] & $\begin{array}{l}\text { IT, Medical } \\
\text { Engineering, } \\
\text { Management }\end{array}$ & $\begin{array}{l}\text { Higher } \\
\text { education }\end{array}$ & LSTM & C \\
\hline
\end{tabular}

From the observation in Table 3, Kaggle Automated Student Assessment Prize (ASAP) conducted a competition dataset. It is sponsored by the William and Flora Hewlett Foundation (Hewlett). Their variables are used to test their scoring capabilities using neural network techniques such as Long Short-Term Memory (LSTM) and Convolutional Neural Network. Dimitrios et al [46] also mention that a deep neural network is capable of using as automatic text scoring using a neural network.

In 2019, Tiliza [45] developed the rule-based Long Short Term Memory (LSTM) classification to assess higher level of cognitive competency via short text answers. This study analysed short free text assessment answers which fell under three criteria. Table 4 shows the three criteria for this study.

Table 4. Criteria for Rule-Based LSTM classification

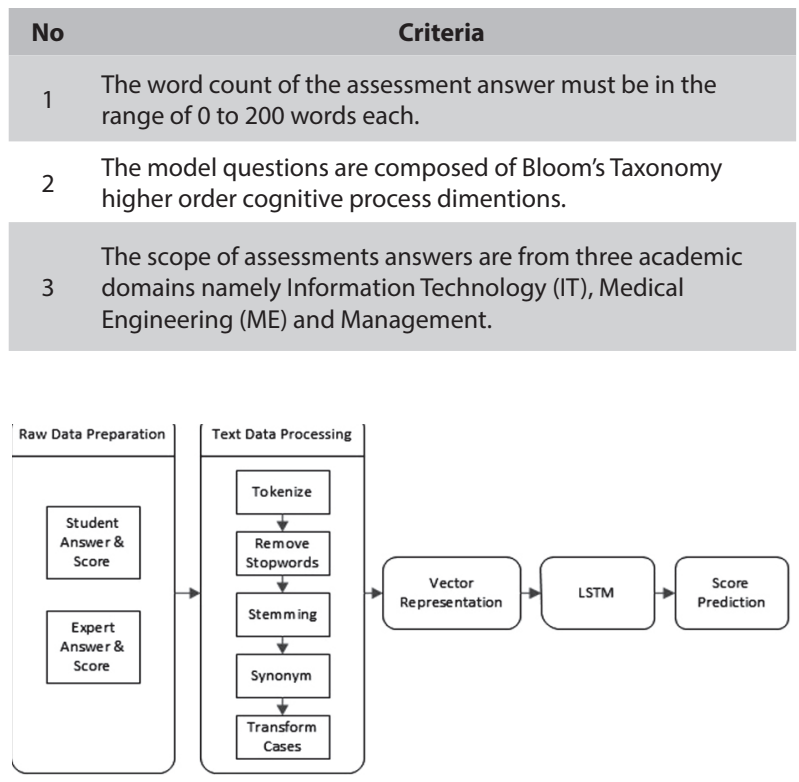

Fig. 4. Technique using Rule-based Long Short Term Memory (LSTM) [47] 
As shown in Fig. 4, the technique uses Rule-Based Long Short Term Memory classification to assess higher-level cognitive competency via short free text answers. The results of the study are that the rule-based LSTM classification achieved a mean correlation of 0.80 , $0.88,0.85$ against test materials sets, Bloom's Taxonomy levels and the academic domain, respectively. Whereas the benchmark results, Latent Semantic Analysis (LSA), show a mean correlation of $0.32,0.332$ and 039 against test material sets, Bloom's Taxonomy levels, academic domain respectively. This is one example of how the Deep learning approach can reduce student failure rates in computer programming.

\section{CONCLUSION}

In conclusion, based on the review of cognitive competency assessment techniques and deep learning in cognitive competency assessment, this research is workable to help reduce of failure rate in the subject.

As to date, there is no research in this field that applied deep learning. For now, there is only research on short free text answers [45].This study will concentrate on the Cognitive domain of Bloom's Taxonomy, where we will evaluate student's programming exercise in $C$ language programming. This research also covers both Higher-Order Thinking Skills and Lower-Order Thinking Skills. With this guideline, we can identify the student's weakness and motivate the student to learn computer programming. By this research, the student and lecturer will able to identify the weaknesses at the early stage and this will help student to pass the subject.

\section{REFERENCES}

[1] Ministry of Education Malaysia (MoE), "Malaysia Education Blueprint 2015-2025 (Higher Education)", Vol. 2025, p. 40, 2015.

[2] C. Douce, D. Livingstone, J. Orwell, "Automatic test-based assessment of programming: a review", Journal on Educational Resources in Computing, Vol. 5, No. 3, 2005, pp. 1-13.

[3] B. C. Surve, B. R. Londhe, "Artificial Intelligence based assessment and development of student's Non-cognitive skills in Professional Education through an online Learning Management System", Proceedings of the $4^{\text {th }}$ International Conference on Inventive Systems and Control, Coimbatore, India, 8-10 January 2020, pp. 329-336.

[4] J. Bennedsen, M. E. Caspersen, "Failure rates in introductory programming - 12 years later", ACM Inroads, Vol. 10, No. 2, 2019, pp. 30-35.
[5] Simon et al., "Pass rates in introductory programming and in other STEM disciplines", Proceedings of the Working Group Reports on Innovation and Technology in Computer Science Education, December 2019, pp. 53-71.

[6] R. Gao, "Reforming to improve the teaching quality of computer programming language", Proceedings of the $6^{\text {th }}$ International Conference on Computer Science \& Education, Singapore, 3-5 August 2011 pp. 1267-1269.

[7] D. Jaithavil, N. Kuptasthien, "An adaptive algorithm for learning computer programming course", Proceedings of the $15^{\text {th }}$ Int. CDIO Conference Aarhus University Aarhus, Denmark, July 2019.

[8] N. Farahah Abdul Halim, D. Nincarean Eh Phon, "Mobile Learning Application Impact Towards Student Performance in Programming Subject", IOP Conference Series. Materials Science and Engineering, Vol. 769, No. 1, 2020.

[9] J. H. Block, "The 'C' in CBE", Educational Research, 1978.

[10] W. G. Spady, K. J. Marshall, "Beyond traditional outcome-based education", Educational Leadership, Vol. 49, No. 2, 1991, pp. 67-72.

[11] A. R. M. Zaghloul, "Assessment of lab work: A three-domain model; Cognitive, affective, psychomotor", Proceedings of the American Society for Engineering Education Annual Conference \& Expositionpp, 2001, pp. 2279-2285.

[12] G. Kasilingam, M. Ramalingam, E. Chinnavan, "Assessment of learning domains to improve student's learning in higher education", Journal of Young Pharmacists, Vol. 6, No. 1, 2014, pp. 27-33.

[13] A. Lajis, H. Md Nasir, N. A. Aziz, "Proposed assessment framework based on bloom taxonomy cognitive competency: Introduction to programming", Proceedings of the $7^{\text {th }}$ International Conference on Software and Computer Applications, February 2018, pp. 97-101.

[14] J. Conklin, "Book review of: "A Taxonomy for Learning, Teaching, Assessing: A Revision of Bloom's Taxonomy of Educational Objectives", Vol. 18345, 2005, pp. 22-25. 
[15] L. W. Anderson et al., Taxonomy for_Assessing a Revision OF BIOOM'S TaxONOMy OF EducatiONal Objectives. 2001.

[16] R. E. Mayer, "A taxonomy for computer-based assessment of problem solving", Computers in Human Behavior, Vol. 18, No. 6, 2002, pp. 623-632.

[17] R. Tong, B. P. Lim, N. F. Chen, B. Ma, H. Li, "Subspace Gaussian mixture model for computer-assisted language learning", Proceedings of the IEEE International Conference on Acoustics, Speech and Signal Processing, Florence, Italy, 4-9 May 2014, pp. 5347-5351.

[18] Z. Ullah, A. Lajis, M. Jamjoom, A. Altalhi, F. Saleem, “Bloom's taxonomy: A beneficial tool for learning and assessing students' competency levels in computer programming using empirical analysis", Computer Applications in Engineering Education, 2020, pp. 1-13.

[19] R. C. F. Sun, E. K. P. Hui, “Cognitive competence as a positive youth development construct: A conceptual review", The Scientific World Journal, Vol. 2012, 2012, pp. 21-23.

[20] A. Lajis, N. A. Aziz, "NL scoring and bloom competency test: An experimental result", Proceedings of the $6^{\text {th }}$ International Conference on Ubiquitous Information Management and Communication, February 2012, pp. 1-5.

[21] B. P. Mitchell Tom, Russel Terry, "Towards robust computerised marking of free-text responses", 2002.

[22] P. Wiemer-Hastings, K. Wiemer-Hastings, A. C. Graesser, "Improving an intelligent tutor's comprehension of students with Latent Semantic Analysis", Proceedings of Artificial Intelligence Education, 1999, pp. 535-542.

[23] F. A. G. Wael, "Short Answer Grading Using String Similarity And Corpus-Based Similarity", International Journal of Advanced Computer Science and Applications, Vol. 3, No. 11, 2012.

[24] M. Mohler, R. Bunescu, R. Mihalcea, "Learning to grade short answer questions using semantic similarity measures and dependency graph alignments", Proceedings of the $49^{\text {th }}$ Annual Meeting of the Association for Computational Linguistics: Human Language Technologies, Vol. 1, 2011, pp. 752-762.
[25] M. Mohler, R. Mihalcea, "Text-to-text semantic similarity for automatic short answer grading", Proceedings of the $12^{\text {th }}$ Conference of the European Chapter of the $\mathrm{ACL}$, Athens, Greece, March 2009, pp. 567-575.

[26] S. Buyrukoglu, F. Batmaz, R. Lock, "A new marking technique in semi-Automated assessment", Proceedings of the $12^{\text {th }}$ International Conference on Computer Science and Education, Houston, TX, USA, 22-25 August 2017 pp. 545-550.

[27] Z. Ullah, A. Lajis, M. Jamjoom, A. H. Altalhi, J. Shah, F. Saleem, "A rule-based method for cognitive competency assessment in computer programming using bloom's taxonomy", IEEE Access, 2019.

[28] Y. Zhang, J. Li, D. Wu, Y. Du, "Improving Student Skills on Parallel Programming via Code Evaluation and Feedback Debugging", Proceedings of the IEEE International Conference on Teaching, Assessment, and Learning for Engineering, Wollongong, NSW, Australia, 4-7 December 2018, pp. 1069-1073.

[29] P. R. G. M. S. P. Molins-Ruano, C. González-Sacristán, F. Díez, "Adaptive Model for Computer-Assisted Assessment in Programming Skills", International Journal of Engineering Education, 2000.

[30] R. Gacitua, M. Dieguez, J. Diaz, S. Sepulveda, "A flexible and systematic teaching framework to develop cognitive skills through programming courses", Proceedings of the $38^{\text {th }}$ International Conference of the Chilean Computer Science Society, Concepcion, Chile, 4-9 November 2019.

[31] Z. Zou, Y. Zhang, J. Li, X. Hei, Y. Du, D. Wu, “EasyHPC: An online programming platform for learning high performance computing", Proceedings of the $6^{\text {th }}$ International Conference on Teaching, Assessment, and Learning for Engineering, pp. 432-435.

[32] L. Echeverría, R. Cobos, L. Machuca, I. Claros, “Using collaborative learning scenarios to teach programming to non-CS majors", Computer Applications of Engineering Education, Vol. 25, No. 5, 2017, pp. 719-731.

[33] H. Cheers, M. Javed, Y. Lin, S. Smith, "Exploring a Comprehensive Approach for the Automated Assessment of UML", Proceedings of the $8^{\text {th }}$ International Congress on Advanced Applied Informatics, Toyama, Japan, 7-11 July 2019, pp. 133-139. 
[34] P. E. Robinson, J. Carroll, "An online learning platform for teaching, learning, assessment of programming", Proceedings of the IEEE Global Engineering Education Conference, Athens, Greece, 25-28 April 2017, pp. 547-556.

[35] R. Romli, S. Sulaiman, K. Z. Zamli, "Test data generation framework for Automatic Programming Assessment", Proceedings of the 8th Malaysian Software Engineering Conference, 23-24 September 2014, pp. 84-89.

[36] D. Galan, R. Heradio, H. Vargas, I. Abad, J. A. Cerrada, "Automated Assessment of Computer Programming Practices: The 8-Years UNED Experience", IEEE Access, Vol. 7, 2019, pp. 130113-130119.

[37] R. Conejo, B. Barros, M. F. Bertoa, "Automated Assessment of Complex Programming Tasks Using SIETTE", IEEE Transactions on Learning Technologies, Vol. 12, No. 4, 2019, pp. 470-484.

[38] G. Polito, M. Temperini, A. Sterbini, "2TSW: Automated assessment of computer programming assignments, in a gamified web based system", Proceedings of the 18th International Conference on Information Technology Based Higher Education and Training, Magdeburg, Germany, 26-27 September 2019, pp. 1-9.

[39] R. Li, Y. Zhu, Z. Wu, "A new algorithm to the automated assessment of the Chinese subjective answer", Proceedings of the International Conference on Information Technology and Applications, Chengdu, China, 16-17 November 2013, pp. 228-231.

[40] M. A. I. Situ Nurulain Mohd Rum, "Metocognitive Support Accelerates Computer Assisted Learning for Novice Programmers", Educational Technology \& Society, Vol. 20, No. 3, 2017, pp. 170-181.
[41] M. Kramer, P. Hubwieser, T. Brinda, "A competency structure model of object-oriented programming", Proceedings of the International Conference on Learning and Teaching in Computing and Engineering, Mumbai, India, 31 March-3 April 2016, pp. 1-8.

[42] K. Taghipour, H. T. Ng, "A neural approach to automated essay scoring", Proceedings of the Conference on Empirical Methods in Natural Language Processing, Austin, Texas, USA, November 2016, pp. 1882-1891.

[43] F. Dong, Y. Zhang, J. Yang, "Attention-based recurrent convolutional neural network for automatic essay scoring", Proceedings of the $21^{\text {st }}$ Conference on Computational Natural Language Learning, Vancouver, Canada, August 2017, pp. 153-162.

[44] J. Z. Sukkarieh, J. Blackmore, "C-rater: Automatic content scoring for short constructed responses", Proceedings of the $22^{\text {nd }}$ International Florida Artificial Intelligence Research Society Confenrence, 2009, pp. 290-295.

[45] T. A. Mat, A. Lajis, H. Nasir, "Text Data Preparation in RapidMiner for Short Free Text Answer in Assisted Assessment", Proceedings of the IEEE $5^{\text {th }}$ International Conference on Smart Instrumentation, Measurement and Application, Songkhla, Thailand, 28-30 November 2018, pp. 28-30.

[46] D. Alikaniotis, H. Yannakoudakis, M. Rei, "Automatic text scoring using neural networks", Proceedings of the 54th Annual Meeting of the Association for Computational Linguistics, Berlin, Germany, August 2016, pp. 715-725.

[47] T. A. Mat, "Rule-based LSTM classification to assess higher level cognitive competency via short free text answer", 2019. 